\title{
Official Crime Statistics versus Fear of Crime of the Citizens in a Hungarian Small Town
}

\author{
Andrea PÖDÖR and Monika DOBOS \\ ${ }^{1}$ University of West Hungary Székesfehérvár / Hungary ·pa@geo.info.hu
}

This contribution was double-blind reviewed as extended abstract.

\begin{abstract}
A wide range of GIS/map based crime statistics are available on line all over the world. However, the public opinion of these statistics is that they do not show the real extent of crime (NYÍRI 2005). This study attempts to test the reliability of crime statistics by mapping residents' fear of crime. The result supports the idea that public perception of crime may be different from official data. Therefore it may be useful and necessary to test the citizens' opinion as an essential requirement in planning, policy and law enforcement strategies to increase their effectiveness.
\end{abstract}

\section{Introduction}

Modern law enforcement has a strong technical background (LEVINE 2004). In contemporary law enforcement, offices take care of maintaining websites for the citizens to show crime statistics. In Europe, map based crime statistics are usually available at country, or regional level, whereby only a few countries provide crime data at municipality level. In Hungary police recently started a new application for the public. (http://bbterkep.police.hu/ mapdisplay/bu.html, last visited 05.01.2013).

According to sociologists there is a gap between the official level of reported crime and the amount of crime in the community (COLEMAN \& MOYNIHAN 1996). Researchers admit that the official crime statistics have some limitations: (1) some crimes are not reported due to unawareness, fear of victimisation, lack of confidence in police, incapability to understand etc., (2) attitude of police can influence the statistics due to employing different categories, campaigning against certain crimes, shifting between operational techniques like community policing to zero tolerance, (3) changes in the number of policemen and legislation, and (4) social and economical changes.

Thus, many people think that crime statistics are not relevant to the real situation. This notion is also supported by a European survey (NYíRI 2005), which found that only half of the crimes are reported to the police. Crimes such as car $(89 \%)$ and motorcycle theft $(82 \%)$, burglary and housebreakings $(81 \%)$, theft from a car $(63 \%)$, robbery $(59 \%)$, and theft of personal property $(54 \%)$ are usually reported to the police. Emotionally sensitive crimes on the other hand, like sexual incidents, are less frequently reported to police (NYÍRI 2005). 
Therefore it is necessary to study the opinion of the citizens about crime in their municipalities and habitat (LEDERER \& LEITNER 2012, FUHRMANn et al. 2013). The authors analysed whether the official crime statistic data correlates with the citizens' perception. In this study, official crime statistics were provided on maps by the police, and the opinion of the citizens was subsequently compared to it for the same time period.

\section{Method}

\subsection{Study area}

For the study, Kalocsa, a small sized settlement with a population of approximately 17000 was selected. Kalocsa is a town which represents the majority of the settlements in Hungary. Compared to the crime statistics of the whole country it has an average rate of crime. The town - according to the integrated urban development strategy - has 11 separable parts: (1) Városközpont - the inner city, (2) Kórház - surroundings of the hospital the metropolitan area (3) Homokgyör- mixed-use industrial and commercial area with hobby gardens along the "Vajas" channel (4) Eperföld - residential area with blocks of houses (5) Szölőkköze - residential area (6) Iparterület -industrial area with problems of annoying smell and noise pollution: (7) Szénáskert - residential area with rows of semidetached houses (8) Bürgerkert - newly developed residential area with family houses (9) Negyvenszállás - country-like residential area with approximately 1-2 hundred inhabitants (10) Meszesi Duna-part - water-management area with water sports facilities and a few hobby-gardens (11) Külterület - mainly agricultural area (Fig. 1).

In this study the comparison between official crime statistics and the opinion of the citizens was based on the above listed districts.

\subsection{Data extraction from official crime statistics}

Statistical data for the period between 05.01.2012 and 05.01.2013 was used. The data was extracted from the official crime map of Hungary. On this map, data is available with 30 days delay on different levels: country, county, and settlement. At the settlement level, the map shows the location of each crime with a point symbol. The following crime types were shown on the map: violent crimes against persons, theft, car and motor theft, car breaking, burglary, vandalism, robbery, violence and disruption, as well as offence against property.

We used the settlement level data and aggregated it by the eleven zones of the city, defined according to the urban development strategy.

\subsection{Survey on the fear of crime of the citizens}

Participants were randomly selected pedestrians on 11/2012. 92 persons responded the survey; all of them were interviewed personally with the help of a pre-prepared questionnaire.

The questionnaire contained 13 questions. 5 of the questions were personal information: age, sex, marital status, number of children, type of the place of residence. 8 questions referred to the status of the public safety, the habitat of the offenders, whether the 
respondent had ever been a victim of any crime, the opinion about law enforcement strategies and crime map. The last two questions included the map of Kalocsa with the 11 zones on it. In this part of the questionnaire the participants had to evaluate the status of the public safety of the previous year in Kalocsa in the 11 zones. This part of the questionnaire helped to analyse the difference between the official statistics and the fear of crime among citizens. In the questionnaire, the respondents had to categorize each zone to their relative safety. They had 4 choices: (1) safe, (2) less safe, (3) dangerous, and (4) avoid during night. It was also possible to combine categories: safe but to be avoided during night. The last question required sufficiently more time from the participants. Using the map for each crime type (see 2.1) they had to create a ranking of the 11 zones of Kalocsa. The first zone in the rank meant that the respondent thought that a given type of crime is most typical in that zone, the last meant that the least typical.

\section{Results}

More than half of the participants were female (54\%), most of the participants belonged to the age groups $18-30(32 \%)$, and $45-60(33 \%), 41 \%$ of the participants were married but many of them had no children (45 persons). $64 \%$ of the participants were living in their own detached or semi-detached house, $23 \%$ of them in their own flat or apartment, $13 \%$ of them in tenancies.

$35 \%$ of the respondents evaluated public safety as acceptable, $30 \%$ were satisfied with it, $20 \%$ of them evaluated as bad, $15 \%$ of them evaluated it as good, and none of them thought that it was very bad. $56 \%$ of the answers showed that the majority of people thought that the offenders were local citizens. Only $17 \%$ were victims of any types of crime. Concerning the effectiveness of the various law enforcement strategies, the answers of the respondents were quite diverse. $82 \%$ of them had no knowledge about the official crime map, but they found it a very good initiative.

The analyses of the last two questions show that the respondents conceived the inner part, zone 1, the surroundings of the hospital, zone 2, and the Bürgerkert (zone 8) as safe, while most of them found the outskirts of the city (zone11) and the Szölökköze (zone 5) residential area dangerous and avoidable at night (Fig. 1.). The reason behind this finding is that the outskirts of the city are lacking of public lighting. The other dangerous part is widely regarded as an area full of people with a deprived lifestyle.

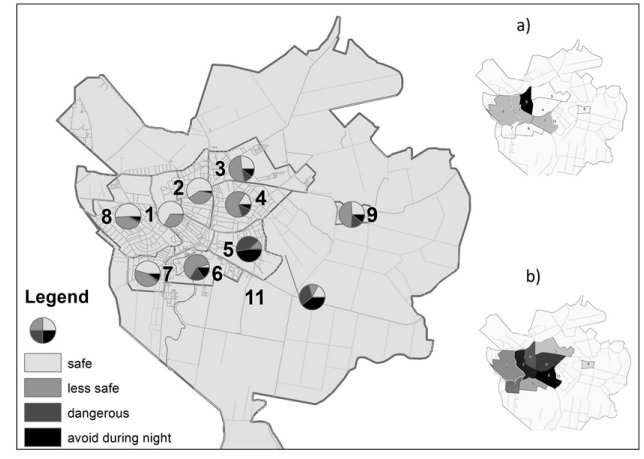

Fig. 1:

The perception of safety according to the citizens of Kalocsa. a) official crime statistics and b) citizen's perception of robberies in Kalocsa 
The vision of the citizens outlined above was compared to the official crime statistics and analysed by each crime type. The number of reported robberies (Fig. 1 a) in zone 5 is much lower than the expectations of the citizens (Fig. 1 b). Similarly people presumed much more crime in zone 3, but no crime was reported in the examined period. In some cases the prejudice may have some important impact on the judgment of the respondents, like in the case of zone 5. The official crime statistics indicate that the inner part of the city is more affected by robbery; although citizens have a similar perception of the status of robberies as in other zones.

\section{Conclusion and Outlook}

This study supports the idea that crime statistics have to be carefully analysed, not just because of unreported crimes, but other factors which can influence the fear of crime. In the future, the opinion of the citizens could be taken into consideration in the planning of law enforcement activities. The results of the study reveal that there can be significant discrepancies between official data and the perception of citizens.

The outlined paper based survey can be substituted with web or mobile applications, as the usage of smartphones among the citizens is widespread, enabling their involvement in crowdsourcing activities, such as valuating their surroundings in respect of fear of crime. These crowdsourced data can reveal the discrepancy between official data and the perception of citizens, so that communities can plan more effective law enforcement activities in the future, concentrating on certain areas.

Acknowledgements: The authors would like to thank the unknown reviewers for their valuable comments, and András Révész for refining the English text.

\section{References}

Coleman, C. \& Moynihan, J. (1996), Understanding crime data: haunted by the dark figure. Open University Press. ISBN 0-335-19519-9.

DoBos, M. (2013), Bünügyi statisztikai adatok feldolgozása térinformatikai szoftver segítségével Kalocsán. Székesfehérvár, NYME GEO.

Fuhrman, S., Huynh, N. T. \& Scholz, R. (2013), Comparing fear of crime and crime statistics on a university campus. In: LEITNER, M. (Ed.), Crime Modeling and Mapping Using Geospatial Technologies. Heidelberg, Springer, 446 p.

LEDERER, D. \& LEITNER, M. (2012), Erfassung der stadtteilspezifischen Kriminalitätsfurcht und Verortung von Kriminalitätsfurchträumen in Linz. In: STROBL, J., BLASCHKE, T. \& GRIESEBNER, G. (Eds), Applied Geographic Information Technology 2012. Berlin/ Offenbach, Wichmann.

Levine, N. (2004), "Journey to Crime Estimation.” In: CrimeStat III: A Spatial Statistics Program for the Analysis of Crime Incident Locations, Chapter 10, edited by N. LEVINE. Houston, TX, Ned Levine \& Associates/The National Institute of Justice, http:// www.icpsr.umich.edu/crimestat.

NYIRI, Z. (2005), Crime and Security in European Capitals. EU ICS Consortium working paper. 